\title{
Maps and Figures
}

Map 1: Specialist Towns of Western Tamil Nadu, India 2

Map 2: Tiruppur: Coimbatore District, Tamil Nadu State 4

Map 3: Tiruppur: Density of Firms by Area 30

Figure 1: Apparel Export Earnings from Tiruppur, 1987-1997

Figure 2: Quantity of Apparel Exports from Tiruppur, 1987-1997

Figure 3: The Knitwear Production Complex in Tiruppur, c. 1998

Figure 4: Composition of Employers' Associations by Routes

Figure 5: Distribution of SIHMA and TEA Owners by Stitching Machines Owned

Figure 6: Distribution of SIHMA and TEA Owners by Machine Capital Owned

Figure 7: Distribution of SIHMA and TEA Owners by Business Volume

Figure 8: SIHMA Members, 1956-1994 